\title{
Cumulative effects of policy and management actions on ecosystem services. Challenges and methodological approaches in The Future Okavango project
}

\author{
Achim Röder, Marion Stellmes, Stephanie Domptail, Annette Eschenbach, Manfred \\ Finckh, Alexander Gröngröft, Jörg Helmschrot, Michael Pröpper, Anne Schneibel \& \\ Johannes Stoffels
}

\begin{abstract}
The Okavango Basin encompasses a wide range of ecosystems and, corresponding to its extension across Angola, Botswana and Namibia, a multitude of communities with diverse socio-economic contexts, that in turn are determined both, by local traditions and regional and national policies. With the river acting as a connecting element, managing the use of natural resources under consideration of conservation issues is a challenging task. The interdisciplinary research project "The Future Okavango" (TFO) aims at contributing to integrated, sustainable land management by providing scientific support to stakeholders from local to national levels. The region under investigation, a system of woodlands, floodplains and extended wetlands is of crucial global importance for biological diversity. Simultaneously it is threatened by rapid transformation through climate change, population growth and anthropogenic over-utilization of natural resources, which may amplify land and water conflicts. The project adopts an approach of mapping and valorising a set of representative ecosystem services and the underlying ecosystem functions. Since these are provided at different spatial and temporal scales, and can show varying properties at different scales, a multi-scale approach is required that covers services from the plotscale to the full Okavango Basin area. Besides the issue of multi-scale variation, cumulative effects may occur between different processes in both, the spatial and temporal dimension, and causing off-site effects or services being partially determined by past processes. In this paper we identify key issues in the assessment process in a wider conceptual context and describe mapping and assessment procedures. Finally, we introduce the concepts utilized to integrate sectorial assessments of ecosystem services and provide an example of an integrated assessment for a theoretical case study in Northern Namibia.
\end{abstract}

Keywords: earth observation; ecosystem service assessment; ground-based mapping; observation scales; socio-economic evaluation.

Os efeitos cumulativos das ações de política e de gestão em serviços ecossistêmicos. Desafios e abordagens metodológicas no projeto "The Future Okavango".

Resumo: A bacia do Okavango abrange uma ampla gama de ecossistemas e correspondente à sua extensão através de Angola, Botsuana e Namíbia uma infinidade de comunidades com diferentes contextos socioeconômicos que por sua vez são determinados pelas tradições locais e pelas políticas regionais e nacionais. Com o rio agindo como elemento de ligação, gerir o uso dos recursos naturais tendo em consideração as questões de conservação é uma tarefa desafiadora. O projeto de pesquisa interdisciplinar "The Future Okavango" (TFO) visa contribuir para uma gestão integrada e sustentável do solo, fornecendo apoio científico para os interessados em nível local e nacional. A região pesquisada, um sistema de florestas, várzeas e pântanos expandidos, é de importância crucial global para a diversidade biológica. Simultaneamente, é ameaçada por uma rápida transformação através da mudança climática, do crescimento populacional e da sobreutilização antrópica dos recursos naturais, que podem aumentar os conflitos da terra e da água. O projeto adota uma abordagem de mapeamento e valorização de um conjunto de serviços ecossistêmicos representativos e as funções dos ecossistemas subjacentes. Uma vez que esses são fornecidos em diferentes escalas espaciais e temporais e podem mostrar propriedades variadas em escalas diferentes, é adotada uma abordagem multiescala que abrange os serviços da escala das parcelas à área total da bacia do Okavango. Além da questão da variação multiescala, podem acorrer efeitos cumulativos entre diferentes processos nas duas dimensões, espacial e temporal, e fazer com que efeitos ou serviços fora da área sejam parcialmente determinados por antigos processos. Neste trabalho, identificamos as questões-chave no processo de avaliação, em um contexto conceitual mais amplo, e descrevemos os procedimentos de mapeamento e avaliação. Finalmente, apresentamos os conceitos utilizados para integrar as avaliações setoriais dos serviços ecossistêmicos e fornecer um exemplo de avaliação integrada para um estudo de caso teórico no norte da Namíbia.

Palavras-chave: avaliação de serviços ecossistêmicos, avaliação socioeconômica, escalas de observação, mapeamento terrestre, observação da terra.

Received: 5 September 2013 - Accepted: 21 December 2013

\section{Introduction}

At all stages of human existence, man has modified and transformed landscapes (Kareiva et al. 2007, Smith, 2007) to appropriate primary production for human use, for instance by obtaining food, fibre, timber or other ecosystem goods (DeFries et al. 2004). The acceleration of land use transformations, coupled with an increasing global population has manifested in an alteration of almost all terrestrial ecosystems (Millennium Ecosystem Assessment, MEA 2005, Steffen et al. 2004) whereby 


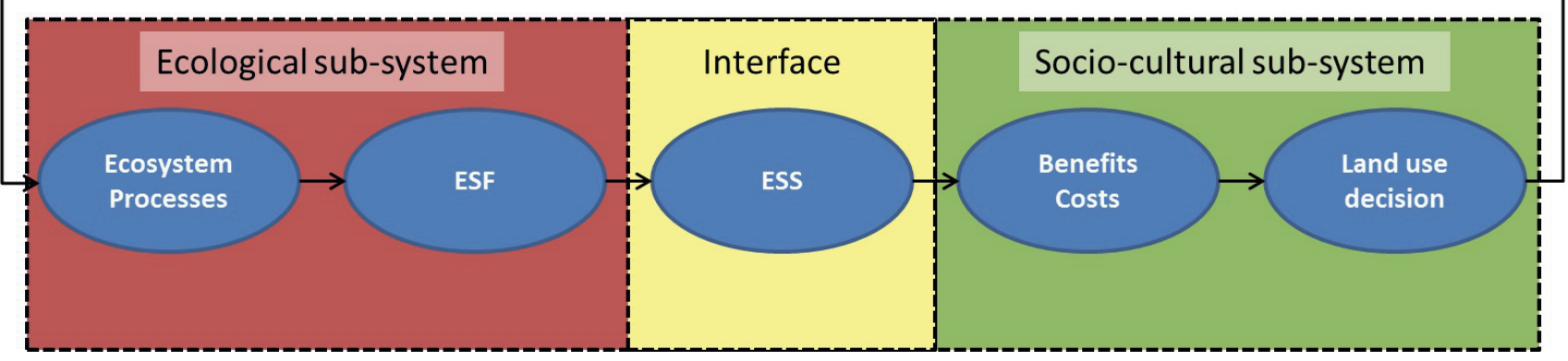

Fig. 1: Sequence of major elements of coupled socio-ecological systems and their role in determining land use.

one-third of all terrestrial net primary production is now estimated to be consumed by humans (Imhoff et al. 2004). The extension of areas of agricultural and pastoral uses coupled with progress in the development of agroindustrial practices has supported unprecedented rates of population growth over decades (Ellis \& Ramankutty 2008). However, globally a positive balance in terms of food production stands opposed to increased greenhouse gas emissions, declining biodiversity, declining freshwater quality, decreasing air quality and increasing soil degradation (Sala et al. 2000, Foley et al. 2005, Butchart et al. 2010, Banwart 2011, Lal 2013).

Owing to the complexity of coupled human and natural systems, designing sustainable management strategies often necessitates trading-off different demands from and pressures on natural resources (Foley et al. 2005). In this context, it is essential to consider social, economic and ecological cumulative effects on ecosystem services (ESS) and underlying ecosystem functions (ESF), that reflect both, the interlinkages between different drivers, as well as rapidly changing social and environmental framework conditions (Chapin et al. 2009, Liu et al. 2007, MEA 2005, Weber et al. 2012). As Figure 1 illustrates, land use decisions are ultimately determined by ecosystem processes, while ecosystem functions, services and their benefits represent the major linkages and are therefore the generic drivers of land use and land use change.

Besides direct links and feedbacks, cumulative effects may occur that are characterized by their space and time dimensions, i.e. effects may accumulate with time within one domain, e.g. the accumulation of carbon in the atmosphere since the beginning of the industrial era, or for a given time step across space, e.g. downstream effects of upstream developments (Jack 2009) or off-site effects related to land use decisions (Lambin \& Meyfroidt 2011, Phalan et al., 2011). In practice, most effects are overlapping and non-linear (Koch et al. 2009), such that for the "Future Okavango" project (TFO) we adopt a modified version of the definition by Hegmann et al. (1999) to characterize cumulative effects as "changes to ESS that are caused by an on- or off-site action in combination with other on-/offsite past, present and future human actions".

Given this, retrospective analyses of the development of tangible ESS/ESF offers valuable insight into the way ecosystems have responded to past management or policy actions (Kapur et al. 2010, MEA 2005). Together with the assessment of the status-quo situation such information is essential to understand dynamic interlinkages of ESS/ESF, inform the development of scenarios, and to calibrate predictive scenario-based models (Weber et al. 2012).

The Okavango Basin represents a highly complex social ecological system, where the variation in physiographic characteristics is reflected by different livelihood strategies. The Okavango river as the connecting element rises in the Planalto of Angola at elevations of $\sim 1300$ $\mathrm{m}$ asl, where an average of $1200 \mathrm{~mm}$ to $1800 \mathrm{~mm}$ of rainfall per year is received (Weber 2013). This supports a network of streams and tributaries that form the Cuito and Cubango rivers with their specific floodplain vegetation composed of reeds and grasses. In the hinterland, vegetation is dominated by Brachystegia woodlands of different density with interspersed grasslands. Land use is dominated by subsistence agriculture, where parts of the woodlands are traditionally used for slash and burn agriculture. After the end of the civil war in 2001, people have been returning to these areas and conversion rates to cropland have been increasing.

Towards the intermediate reaches of the river in southern Angola and northern Namibia, rainfall decreases down to $\sim 600$ $\mathrm{mm}$ (Weber 2013) and vegetation is mainly dominated by Burkea woodlands. While the majority of people rely on subsistence farming, the presence of Rundu, the second-largest city in Namibia, creates market opportunities that impact on adjacent areas. Besides cropping, horticulture is practiced in locations close to the river with access to water, and commercial farming has started to play a role with the creation of irrigation projects.

It is only $50 \mathrm{~km}$ west of the town of Divundu in northern Namibia that the Cuito and Cubango join to form the Okavango River that runs through the Panhandle region and eventually feeds into the Okavango Delta, one of the largest inland deltas in the world. With rainfalls ranging from $450 \mathrm{~mm}$ to 550 $\mathrm{mm}$ (Weber 2013) it is especially the flooding pulse of the river that sustains the large number of plants and animals that dwell on the seasonal and permanent swamps of the Delta and the Mopane and Acacia woodlands and grasslands surrounding it. In the Delta region, subsistence agriculture and the extraction of timber, thatch grass etc. form the basis of most livelihoods, but tourism is an additional source of income for some people. Maun is the major hub for most touristic activities that heavily depend on natural stocks, such as the aesthetic value of ecosystems along the gradient from wetlands to savannas and the diversity of wildlife associated with these.

The three countries bordering the river have individual legislations governing the use of natural resources, which usually originate at central institutions and are implemented in different ways at 
subordinate levels. Commonly, communities make their own decisions regarding the use of natural resources within the framework of statutory and traditional governance and national legislation. The "Permanent Okavango River Basin Water Commission" (OKACOM) has been created between Angola, Namibia and Botswana to deal with transboundary issues and facilitate informed policies.

Reflecting the complex structure of the Okavango system, multiple scale-related methodological challenges emerge. Especially regarding cumulative temporal and spatial effects this system, despite its size, is not a concluded socio-ecological one, but itself is part of a broader political, economic and geographic landscape with its historic temporal relations. These in turn influence the subsystem with multiple trade-offs and additional spatial and temporally cumulative effects.

In this paper we seek to

- Illustrate the challenges in assessing ESS under consideration of cumulative effects in a highly diverse environment

- Describe the ecological and societal mapping and valuation options pursued in TFO

- Demonstrate and discuss an approach for integrating different disciplinary results

\section{Observation scales}

One particular challenge in evaluating ESS/ESF lies in the fact that both, their manifestation, as well as the factors affecting them, play out at largely different scales (Hein et al. 2006), and dependencies exist across space and trough time (Gillson 2009, Rhemtulla \& Mladenoff 2007). In this context, scale refers both to the spatial extent of the area assessed, as well as to the level of detail at which the assessment is being done. Depending on the discipline involved, this may translate into different spatial entities, such as administrational levels or influence spheres in the case of social and political sciences, or to grain and extent in the case of natural sciences. To address the multi-scale nature of many ecological problems, nested approaches are very common, where for a given focal level, the superior hierarchical level provides the general background (e.g. climate

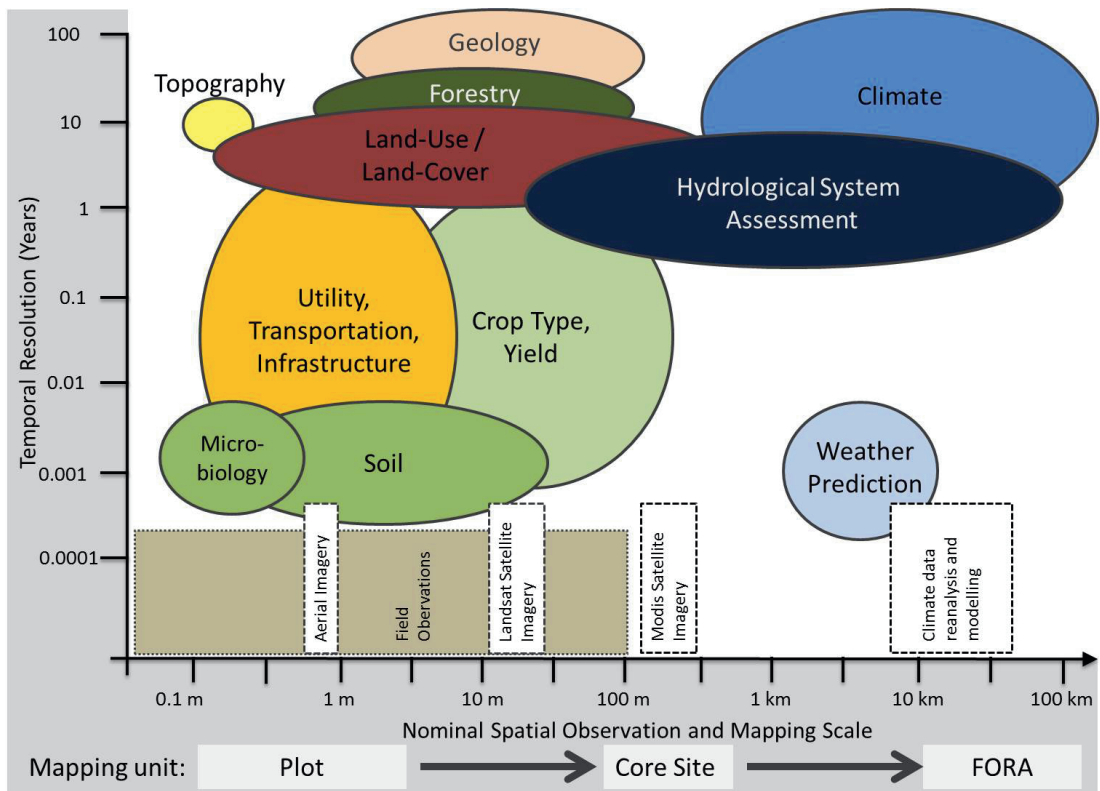

Fig. 2: Spatial and temporal observation scales of selected environmental and socio-economic domains with reference to the spatial grain of mapping methods (modified after Jensen 2007). Note that field observations can cover a wide range of observation grain and extent.

variations, climate change, global economic trends, etc.), while the subordinate hierarchy level represents individual components of the focal level and provides explanatory power (O'Neill et al. 1986). In the time dimension, this is reflected by the concept of slow, intermediate and fast variables (Allen \& Starr 1982, Mulligan et al. 2004).

While these concepts relate to continuous fields in space and time, discontinuous factors, such as management processes or landscape features etc., may cause systems to transform over time and cross tipping point thresholds and move directly, and often irreversibly, from a desired to an undesired state (Scheffer 2009). In the Okavango region, such management processes might be for example the creation of dam features or water extraction for industrial or domestic use that change river flow dynamics, the establishment of large-scale irrigation schemes impacting ecosystem functions, mining activities, deforestation increasing erosion and sediment transport, or the effect of fencing structures that impede herbivore movement (Mbaiwa \& Mbaiwa 2006). At the same time, overarching developments play an indirect, albeit important, role. These include societal developments, such as urbanization, increasing consumerism, changes in income opportunities resulting from touristic investments, or generally changing living conditions and aspirations as a result of better education and access to information. These are added to by local repercussions of regional and global processes, which range from migration due to political or economic reasons to the effect of global markets on local economies.

In addition to these scale categories, the specific TFO focus on the Okavango River adds a directional perspective that needs to be incorporated. As a result, processes that affect ESS/ESF may accumulate in a unidirectional manner from upstream to downstream locations, and include effects such as reduction in overall water amount and quality, discharge rates etc. with all related effects on livelihoods, such as the sustenance of habitats crucial for wildlife conservation, or flood control (Lindemann 2009). Obviously, this poses major challenges to integrated management of water resources and requires particular attention to the involvement of relevant stakeholders (Jakeman \& Letcher 2003). When defining the appropriate observation scale for a given research topic, it is important to ensure that observation scales of different scientific disciplines can be matched. Figure 2 gives an example of the spatial and temporal dimension of selected environmental and socio-economic domains and shows at which mapping scales these are addressed. To incorporate the active Okavango Catchment, the Panhandle region and the Delta in the 
large area analysis, the "Future Okavango Research Area" (FORA) has been defined as shown in Figure 3, which replaces the typical "Catchment" scale used in many studies.

While the level of detail at which ESS/ESF are assessed is highest at the plot scale, the FORA scale allows for a seamless perspective across large areas, while the core site level and its extension using satellite imagery provide a balance of both. Reflecting the diversity in stakeholders from subsistence farmers to national and transnational bodies, the observation units provide direct information, but may also be seen as means of up- and downscaling information, which is consistent with the multi-scale dimension of ESS/ESF (Liu et al. 2007). For instance, major services at the plot-level may be the provision of food, fibre, timber and fuel wood as a result of appropriating savannah woodlands for human use. Yet, at the core site and catchment scales, negative effects on carbon sequestration or biodiversity may be the prevalent aspects, thus illustrating the problem of substitution effects across scales. At the same time, temporally cumulative effects need to be considered in the interpretation of results. These may relate to climatic variations or changes in livelihood situations (e.g. population returning to rural areas after the end of the civil war in Angola), whose effects on ESS only become apparent after a certain temporal lag. The consistent assessment of ESS/ESF and their determining factors at all core areas ensures that spatially dependant effects along the course of the river effects are reflected in the integrated assessment, while aspects of tipping points and thresholds will be treated by specific case studies that will be integrated with the baseline surveys. Figure 3 shows the units addressed by TFO, illustrated using typical spatial mapping levels of earth observation data. In this context, plot level corresponds to unique measurement points on the ground, while the core site level corresponds largely to the stratification and mapping units used for field work and has been defined as $100 \mathrm{~km}^{2}$ sites in TFO, which are positioned at representative locations along the river. The intermediate level shown is addressed based on the same satellite imagery used for analysing the core areas, but extending the spatial data analysis to an area larger than what can be covered by ground-based analyses. Thus, this level serves as an intermediate

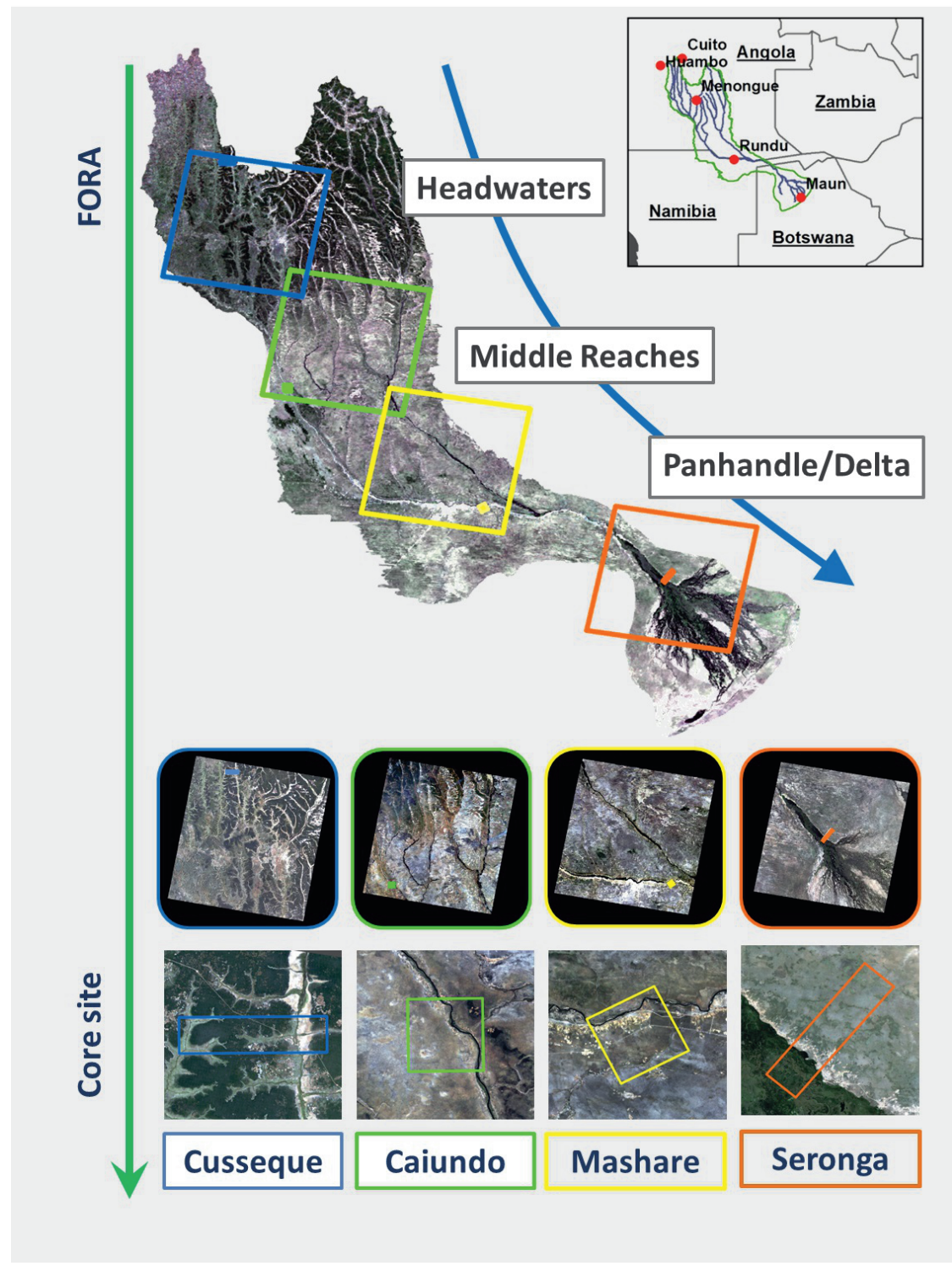

Fig. 3: Distribution of TFO research units and their spatial extension. The core site level is the common reference level for all disciplines; for the FORA level, specific analyses on this level are integrated with the core site analyses, and larger areas covered by satellite imagery are used for integration and upscaling.

level to extend field observations at the plot- and core-site level, and to upscale such information to the FORA level, which in turn is mostly represented using coarse scale satellite imagery, climate data, hydrological modelling etc.

One particular challenge when addressing cumulative effects is their temporal dimension. Especially in the case of in-situ, ground-based assessments without the availability of older data, it is almost impossible to adequately represent previous states. One alternative is to use space-for-time substitution (Pickett 1989), where different locations sharing the same physical characteristics but representing different development stages are selected to understand dynamic processes, such as in the case of different post-fire successional stages of the same vegetation community. When addressing temporal developments that have occurred during the last 40 years, long term remote sensing archives offer the opportunity to investigate this period based on consistent data records, as the present situation recorded by sensors is intrinsically the aggregated result of previous processes, thus representing temporally cumulated effects such as climate variations, changing policy frameworks, conflicts etc. 


\section{From ecological scales to scale for management}

In ecological terms, ESS are provided by service productivity units (Luck et al. 2009), which can relate to different levels, such as single species, populations or landscapes (Morán-Ordóñez et al. 2013). On the other hand, the benefits of ESS are not necessarily realized on the site of their provision. When relating the ecological to the management domain, identifying the connection between the provision of ESS and realization of their benefits is an important aspect that needs to be explicitly addressed (Kremen \& Ostfeld 2005).

Fisher et al. (2009) suggest different possible geographical flow types: in situ, directional and omni-directional flow direction. In situ indicates that an ESS is generated at the same location as it is enjoyed: it has no flow (e.g. soil formation, provision of raw materials); directional indicates that the ESS stems from one location and flows only in a specific direction (e.g. water regulation services provided by forested slopes); omni-directional indicates that ESS stems from one location and flows in the surroundings in all directions (e.g. pollination, carbon sequestration). While in the case of in situ ESS, benefiters and providers share the same location, in the presence of ESS with directional or omnidirectional flows, the benefiters and providers may be two different stakeholders. Stakeholders groups benefiting from the ESS ("beneficiary") or having an impact on the provision of the ESS through their land use management ("provider") should also be identified in the course of analysis in order to conduct the assessment of socioeconomic drivers and values of ESS at the correct scale (Hein et al. 2006, Martin-Lopez et al. 2011). The last useful information in order to guide the assessment of the dynamics of governance system and their relationship with ESS is the access to and impact on ESS by the socio-economic subsystem. Identifying the economic nature of ESS in terms of excludability and rivalry (Costanza 2008) may provide a useful first glance in order to categorize the different ESS.

Table 1 provides an overview of the final ecosystem services investigated in TFO and indicates the most important ecological and societal characteristics as well as directional properties of the realization of their benefits. This approach represents the attempt to understand the human valuation of ecosystem services as part of complex land use strategies. The differentiation of ESS is partially driven by conceptual requirements associated with mapping and valuation strategies. For instance, crop and vegetable growth are individually treated since they are determined by different drivers (e.g. availability of irrigation water, access to markets etc.) and imply different land use strategies. The same accounts for the "Wild Species Diversity" and "Wildlife Growth" services, where diversity has a focus on the number and occurrence of species (both floral and faunal), whereas wildlife growth is incorporating absolute numbers and as such allows to assess human wildlife conflicts or competing demands of farmers vs. people involved in the tourism industry.

A first major group of ESS includes agriculture-related in-situ ESS which are typical private goods. Since currently agricultural activities in the catchment are dominated by small scale subsistence agriculture, the stakeholders concerned are mainly small scale subsistence farmers. Due to the recent and on-going development of industrial agriculture, regional consumers and governments are expected to gain increasing stakes in these ESS (for instance through food security policies).

A second major group consists of ESS which are rival and excludable. They are not private but can be considered to be common (assuming the existence of institutions to manage/regulate them). They arise at the local scale and in situ (Wild Plant Species Diversity, Tree Growth, Thatching Grass) and involve rather community members: their provision depends greatly on land tenure and the existence of institutions for the regulation of harvest. These regulations may stem from traditional governance or from government. In the latter case, due to the strong top-town governance systems in each country of the Okavango River Basin, national and regional governments could become stakeholders, as in the case of forest management in Namibia.

Wildlife Growth (with a focus on larger migrating herbivores and top predators) and Water Supply on the other hand are also rival and excludable but occur at larger scale, and may be considered common good (sensu economics) at the scale of the Okavango Catchment. Indeed wildlife migration and water supply are typical transboundary issues. However, benefits do arise at the local (food, bushmeat revenues, poaching revenues for pelts, pangolin scales, etc.) and regional (touristic income) up to the international level (existence value of species). Thus, the management of these ESS has the potential to generate conflicts if not all relevant stakeholders are explicitly considered.

Three ESS are non-excludable and non-rival, typical public goods (sensu economics). At the local or regional scale and in situ, the ESS Environmental Settings, which encompasses the sense of place (cultural identity and aesthetics) and the spatial configuration of landscape elements (in the sense of patches of the same type of land use or land cover, and with the corresponding configuration dependent functionalities), provides benefits for the whole world as well as to the local land users (similarly to wildlife and species diversity) which brings with it potential conflicts between generations and among stakeholders between modernity (land use change) and tradition (cultural and environmental conservation). The regulation services (climate and hazard) benefit mostly local people. Hazard regulation involves various aspects, such as fire prevention, water regulation etc., with different corresponding properties (e.g. directional properties when linking upstream deforestation to downstream water regulation). Finally, Climate Regulation is considered independent from the stakeholders of the basin and is thus considered in TFO rather as a driver than as an ESS to be managed.

\section{Assessment and mapping methods}

As indicated before, TFO adopts a multiscale assessment strategy, where ESS/ESF are assessed at three generic scales: plot, core site and FORA. Besides direct mapping or measuring, other variables are assessed that are equally important, since they determine the type and value of ESS/ESF supplied by different systems. They include both spatial and non-spatial parameters, such as land use as a primary driver of ecosystem services (De Fries et al. 2004), water availability and use, preferences and determinants of decisions taken by relevant local actors (Lorent et al. 2008), as well as the general political and socioeconomic setting which ultimately drives 


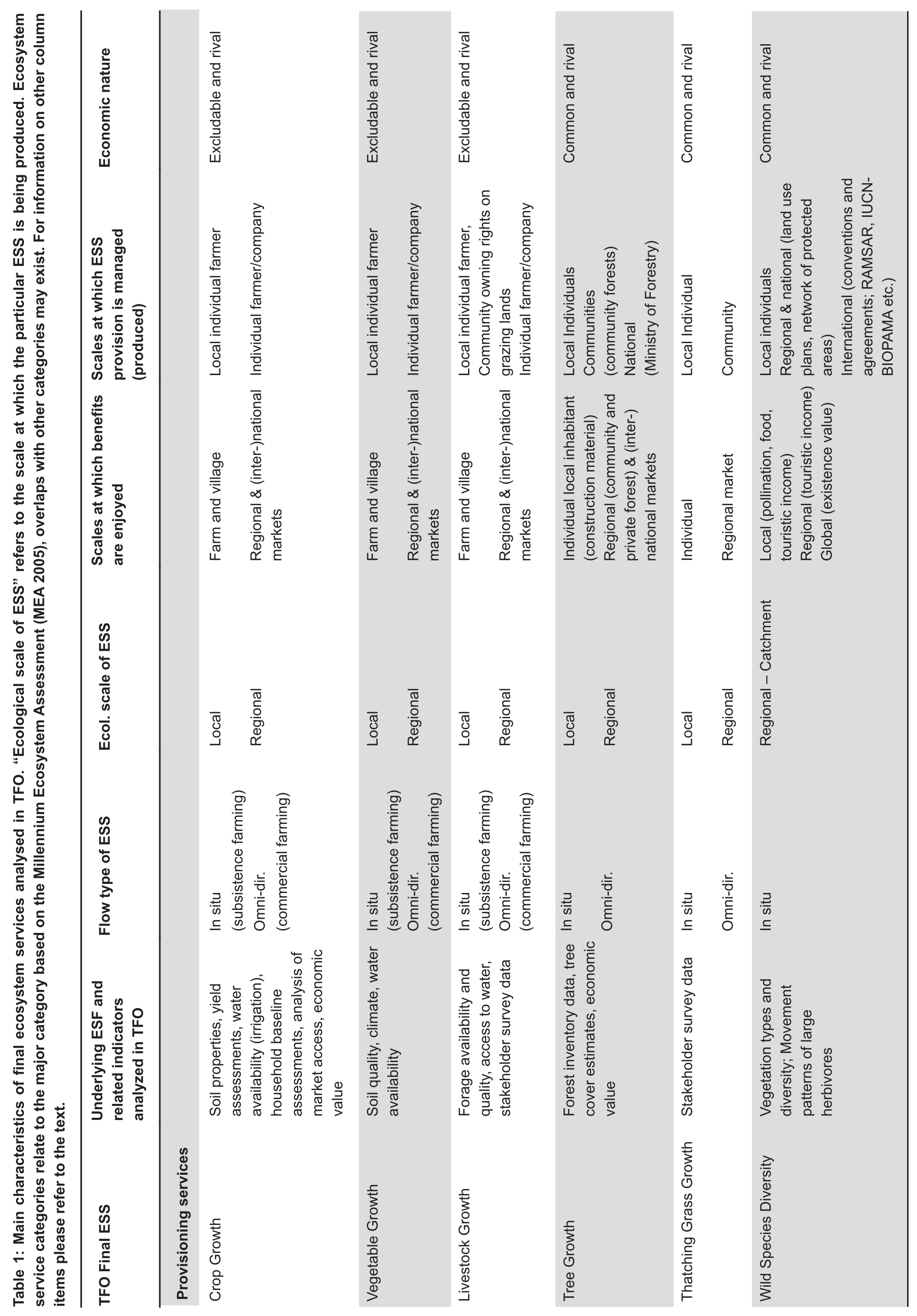




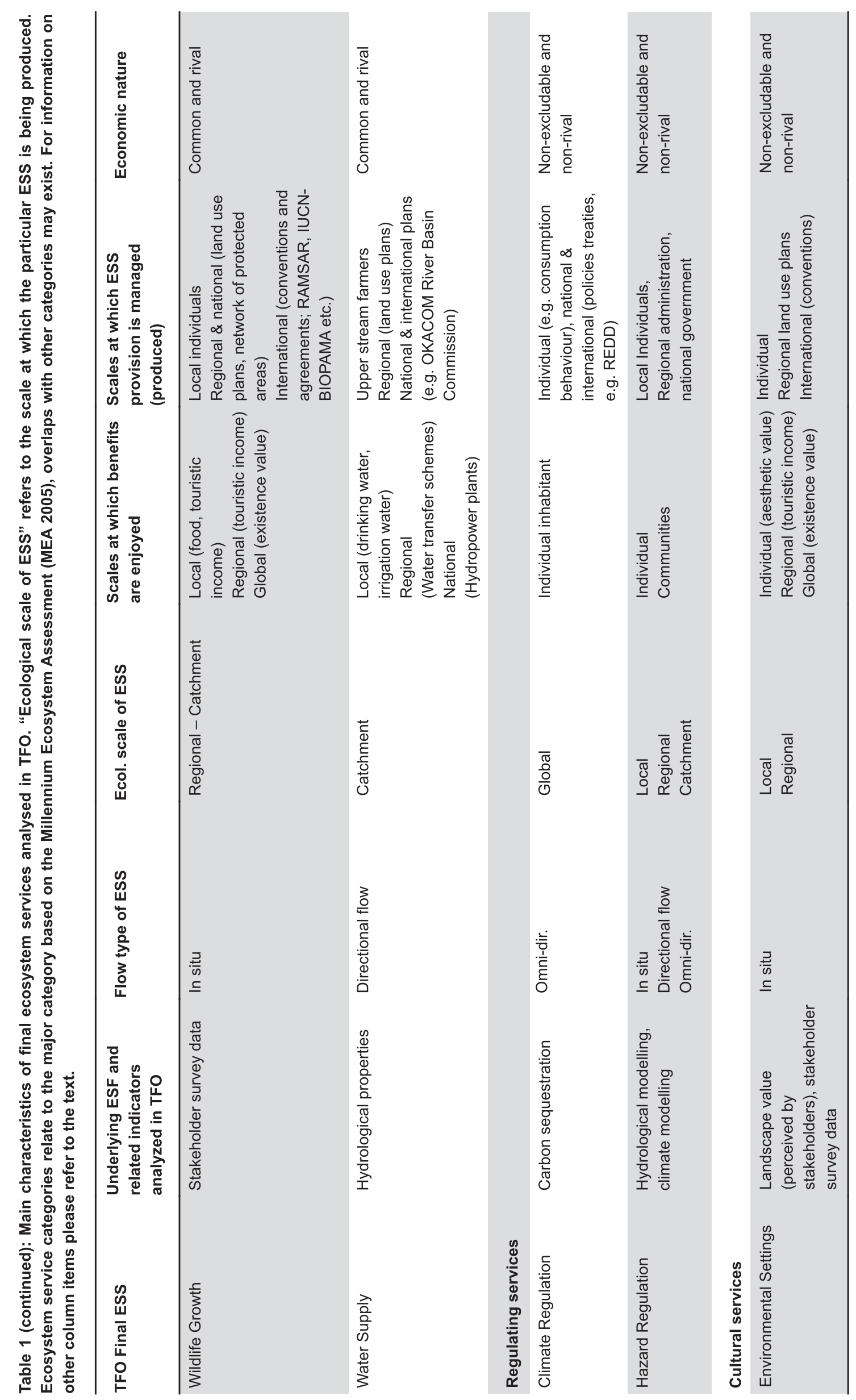




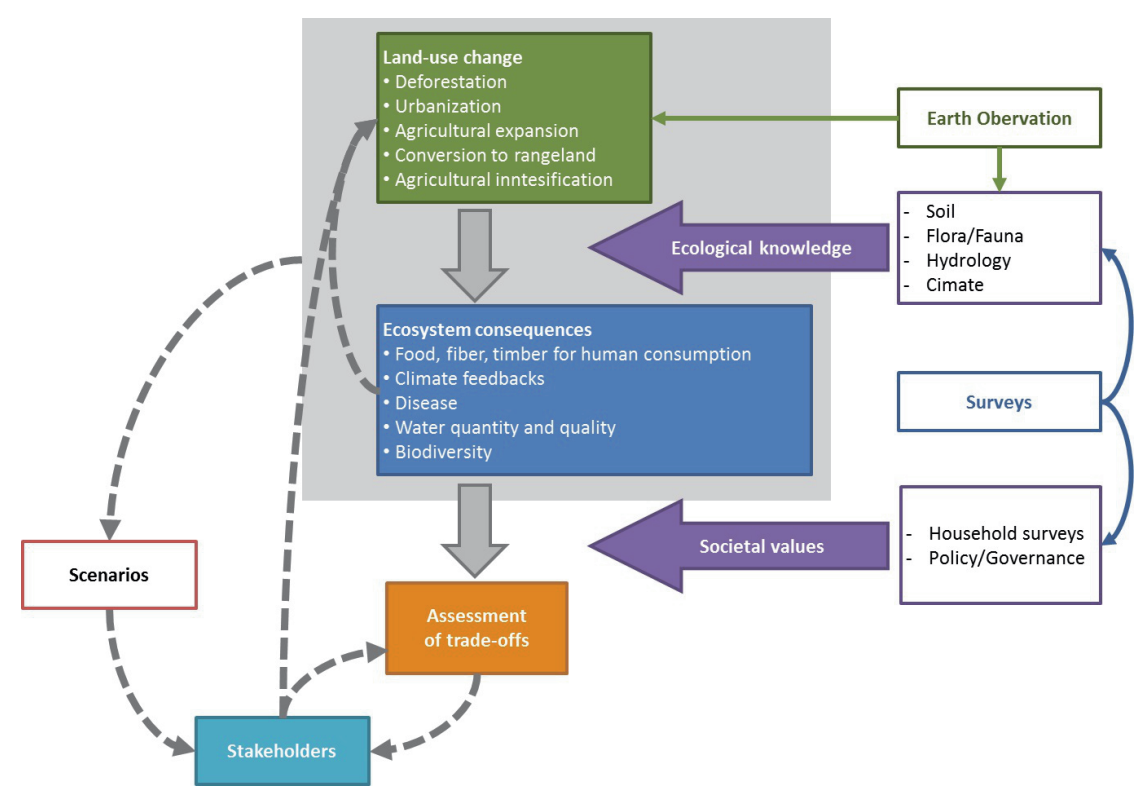

Fig. 4: TFO strategy to assess the impact of land use (change) on ecosystems and services they provide using ecological knowledge. In the next step, societal values are incorporated to assess trade-offs between ecosystem services ultimately triggered by the land use decisions initial to this conceptual model. One important component in this assessment is the utilization of scenarios of future developments to rate the present situation and either confirm or revise land use decisions (modified and extended from DeFries et al. 2004).

many of these decisions. Figure 4 illustrates schematically how these different domains interact to determine ESS/ESF and how TFO intends to estimate trade-offs considering stakeholders views and scenarios developed in the frame of the project (see also Domptail et al. 2013).

The following section illustrates some of the most important components of the assessment strategy adopted by TFO. For the sake of clarity, these will first be presented in their disciplinary contexts, while their integration will be discussed in section 5 .

\section{Ecological scientific knowledge}

\section{Soil}

For the Okavango basin, information about soil properties and their spatial distribution is sparse, coming from international (Jones et al. 2013) or national (Angola: Abdelli \& Jouen 2012; Namibia: Coetzee 2001, Mendelsohn 2009, Ministry of Environment and Tourism 2000; Botswana: De Wit \& Nachtergaele 1990) survey programs, some local studies (Wisch et al. 2009, Strohbach \& Petersen 2007) and goods, and the human capital input needed for their extraction. An intermediate characterization of the landscape structure and representative soils is shown in the factsheets (this issue)

A conceptual approach to bridge the different scales with restricted biophysical spatial information and inclusion of up-to-date knowledge on ecological functioning is based on a knowledgespace approach that represents different degrees of conceptual and computational complexity (Fig. 5). This approach serves to conceptualise the flow of information for the analysis of the influence of landuse change on soil water availability across three scales to yield information for the full research area (FORA). On the upper scale, qualitative knowledge about landscape structure and their land use distribution exists or can be analysed by remote sensing techniques (A). This knowledge is adapted to the landscape (core site) scale (B). Based on improved spatial information and mapping activities, the knowledge on spatial structures can be improved (C). Due to the analysis of soil properties on the plotscale (= soil profile or soil horizon) (D) and the application of soil-water balance modeling approaches (SWAP, (Kroes et al. 2008)), expert knowledge on the role of soils, land-use management and climate on the lowest scale can be evaluated quantitatively (E). In the modeling step, the down-scaled climate data are integrated $(\mathrm{H}, \mathrm{I})$, thus guaranteeing the congruence of the results with other climate related assessments. Since soil mapping is carried out at the landscape scale, the upscaled information of the modeled soil water balances (F) still involves a high degree of computation and complexity and will be assessed with regard to sustainable land-use management options. However, with the further transfer of this information to the FORA (G) the uncertainty with regard to the spatial structures of the region and their internal functioning increases and the qualitative component of expert knowledge increases. With the whole loop of steps from (A) to $(G)$ a substantial improvement of knowledge has been generated which helps to improve future land use decisions on the upper scale.

Knowledge on ecosystem functioning and their interaction with final ecosystem services will be integrated on the core site scale. Depending on the final ESS and the extracted goods under investigation 

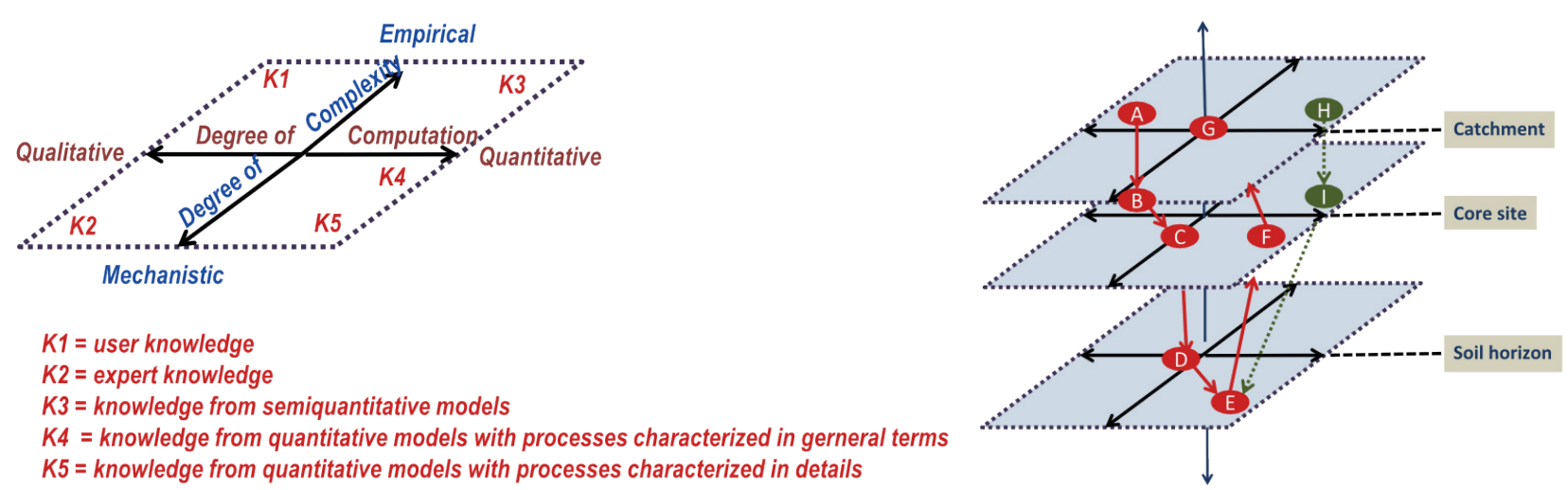

K1 = user knowledge

$K 2=$ expert knowledge

K3 = knowledge from semiquantitative models

K4 = knowledge from quantitative models with processes characterized in gerneral terms

K5 = knowledge from quantitative models with processes characterized in details

Fig. 5: Conceptual approach for the knowledge generation for the influence of land-use change on soil water availability using a multi-scale knowledge space adopted to the TFO project after Bouma (2000). Explanations see text.

relevant aspects of natural condition/capital (Robinson \& Lebron 2010, Dominati et al. 2010), such as climate, soil quality and biological interactions, will be integrated with land use management. In this context, soil quality will be analysed with respect to three pillars, i.e. soil air and water availability, nutrient availability and biological turnover (Eschenbach et al. 2013).

\section{Vegetation}

Quantitative vegetation data for the Okavango catchment is rare, especially for the large Angolan part. To gain system understanding TFO uses an upscaling approach starting with detailed studies at the four core sites. Based on an unsupervised classification of Landsat images of the core sites, vegetation relevés were distributed using a stratified sampling over the core sites. This sampling design allows detailed analyses on vegetation units and habitat types at the core sites and the main environmental and human factors controlling their distribution.

Major vegetation units found in the FORA are strongly related to landscape features showing archetypal combinations of topographical, lithological and hydrological properties. Therefore, using a combination of species distribution modelling (Franklin 2011), vegetation classification, GIS analyses and remote sensing applications a vegetation map will be scaled up to FORA level (see also Stellmes et al. 2013b).

On core site level, temporal cumulative effects on vegetation cover will be addressed by investigating the frequency and intensity of fire on the one hand, and the frequency of slash and burn events on the other hand. Resilience of relevant vegetation units to those impacts and time lags needed for recovery and successional pathways are being studied in TFO using the core areas as representative units. In addition, specific analyses are carried out using remote sensing data (e.g. Stellmes et al., 2013b)

Furthermore, the effect of extending agricultural land use under different land use scenarios will help to identify tipping points for fragile habitat types and functional connections. Spatial analyses of current and (scenario based) future land use systems will allow identifying possible spatial bottlenecks for current ecological systems (e.g. barriers for wildlife migrations) and their respective service provision.

This triple (spatial, temporal and functional) approach will help to establish spatially explicit multi criteria analyses for land use scenarios. An example: improving the road system in the basin makes the vast hinterland accessible to increasingly intensive agricultural exploitation. Road axes constitute spatially explicit vectors triggering land use changes and can be used to model (and subsequently evaluate) land conversion and habitat fragmentation.

In the long term (2100) climate change will become a relevant driver of change at catchment scale. Consequently, species distribution models offer the adequate tool box to predict potential long term impacts at this spatial and temporal scale. This can be addressed by modelling the climatic niche of different species based on present observations and distribution probability functions, and assessing how these niches change by projecting the suitability functions to scenarios of future climate conditions (Franklin 2011, Sommer et al. 2013)

\section{Hydrology}

There is a wide range of hydrological assessment approaches available, ranging from simplified stochastic assessment referring only to recorded time series to process-based hydrological models taking the full water cycle and its relevant processes and components into account. Modelling at catchment and subcatchment scale aims to transfer spatio-temporally variable precipitation into a system output considering the 3dimensional, interlinked geohydrological and plant-physiological processes within a watershed. Hereby, physically-based or conceptual models link lateral and vertical flow dynamics of the water cycle. While process-driven and physicallybased SVAT-models (Soil Vegetation Atmosphere-Transfer) are often utilized for micro-scale applications (Kalma \& Feddes 1993, Flügel \& Smith 1999), more or less simplified storage-process models which cascade water storages are usually applied in meso- and macro-scale studies (Leavesley et al. 1983, Schulze 1995, Krause 2001).

The importance of distributed, processbased catchment models for hydrological system assessments and in particular process understanding is constituted, since such models consider the spatial heterogeneity of a landscape and physical laws described by measured parameters (Flügel 1995, Beven 2001). Distributed models like J2000 (Krause 2001, Fink et al. 2007) which is utilized within the TFO project use the Hydrological Response Units (HRU) approach (Flügel 1995). HRUs are distributed, heterogeneously structured model entities representing specific landscape units of similar response in terms of their hydrological process dynamics. Since each HRU is characterized by a set of parameters 
representing conceptual storages and runoff generation dynamics, the HRU concept can be used to simulate variables controlling the hydrological process dynamics spatially distributive and scaleindependent. Thus, variables like e.g. evapotranspiration, soil moisture, groundwater recharge or surface runoff can be determined either for each HRU, but also as a basin sum, at varying time scales.

Many ecosystem services are delivered at the local scale, but their supply is often controlled by regional or global processes. On the other hand, aggregated local processes might affect regional or even global processes, but they are rarely a simple summation of the services at finer scales (Carpenter et al. 2006). As shown by numerous studies, this is evident for most hydrological services, because of the complexity and variability of hydrological dynamics across various spatio-temporal scales (Tchiguirinskaia et al. 2004, Blöschl 2006). Addressing the multi-scale interaction of hydrologic functions and their relevance for scale-related hydrologic ecosystem functions and services in the Okavango catchment, TFO aims at the assessment of hydrologic ESS such as e.g. groundwater recharge, water availability and water quality by processbased, distributed hydrological modelling of water and sediment fluxes at subcatchment and catchment scale following a nested catchment approach, where information for large areas is developed by aggregating specific submodels (Kralisch \& Krause 2006, Kralisch \& Fischer 2012, Wolski et al. 2006).

With observed, simulated or projected climate data, information on land cover, soils and topography as well as land management as drivers, the model approach utilizing the J2000 model suite will allow for the analysis and assessment of land management and climate change impacts on interrelated hydrological processes across given scales (Helmschrot 2006, Krause et al. 2009, Fink et al. 2007). For example, model exercises are done for all tributaries to understand runoff generation mechanisms in the headwaters. By this, contributions of individual catchments to the overall water balance are quantified and their relevance for the hydrology of Okavango basin can be assessed (Steudel et al. 2013), e.g. the impact of declining precipitation or increasing water extraction for irrigation on groundwater recharge respectively can be identified explicitly at ecosystem, core site or (sub-)catchment scale. Storage functions of wetlands and floodplains affecting streamflow pulsing and baseflow will be individually evaluated based on daily model exercises applied to the headwaters and subcatchments (Helmschrot 2006, Baumberg et al., 2014). In addition, upstream downstream interactions with altered environmental or climate conditions in upper reaches and their impact on downstream water availability provide measures for both land management options (extent of irrigation areas, cropping) and minimum flow requirements to the Okavango Delta.

\section{Earth Observation}

Remote sensing supports mapping of ESS in a spatially explicit, synoptic, consistent and repetitive manner, and therefore matches requirements of cumulative effects assessment as stated before. Today, a wide range of sensor systems placed on space-based and airborne platforms are available. They are characterized by geometric resolution (grain), spatial coverage (extent), repetition rate and history of data acquisition. These need to be selected depending on target processes and areas, and on the type of information product desired. In addition, these systems are equipped with a largely varying number of spectral bands determining their information content. Besides these technical specifications, the history and repetition rate of image acquisition of the different missions and sensors are determining their potential for long-term analyses. Although various approaches for intercalibration across different sensors exist (Jiang et al. 2008, Röder et al. 2005), coherence of information is facilitated by the use of consistent datasets.

Most prominent examples of long-term, globally available data archives are the Advanced Very High Resolution Radiometer run by the National Oceanic Administration (NOAA-AVHRR) and the Landsat systems, available since 1981 and 1972, respectively. In recent years they have been complemented by further relevant sensors, in particular the MODIS (Moderate Resolution Imaging Spectrometer) mission that started in 1999. These are the archetypical examples of the major categories of multi-temporal data: coarse scale imagery with reduced spatial (and often spectral) capabilities, but daily coverage allowing for the provision of different stabilized, multi-day composites on the one hand; and finer scale data with better spatial (and sometimes spectral) discrimination capabilities at the expense of revisit intervals. These data can be considered largely operational and cost-efficient.

In the frame of TFO, the MODIS archive is utilized to infer information on phenology across the whole Okavango catchment (Zhang et al. 2003) based on the 16-day composites of the Enhanced Vegetation Index (EVI), which is in turn used to map major land use systems and functional vegetation units (Udelhoven et al. 2010, see also catchment factsheet, this issue). To reflect the importance of fires as a major driver of ecosystem processes, specific analyses of time sequences of the MODIS fire product are implemented to characterize important aspects such as fire frequency, fire intensity etc. (see Stellmes et al. 2013b).

Given the significance of land use as a driver for ESS/ESF, a baseline survey on land use/cover change is carried out for all core areas using different classification approaches (e.g. Pal \& Mather 2005) to assess effects through time and across space in a comparative way and based on medium-resolution satellite imagery (e.g. Landsat-TM/ETM+/OLI). For the TFO target locations, data availability is highly variable, in particular during the wet season cloud-free images are rare. Yet, the available data allowed the establishment of multi-temporal data sets for the periods of 1990, 2000 and 2010. Such multiseasonal acquisitions within years enable the discrimination of different land surface types based on their seasonal characteristics and the retrospective analysis of land use change in the past.

In addition to land use mapping, iterative Spectral Mixture Analysis (Rogge et al. 2006) will be utilized to derive quantitative estimates of the abundance of surface elements, e.g. tree cover. Resulting land use (change) and cover maps are further analysed in relation to potential driving factors, to quantify for instance the impact of roads as vectors of conversion from woodland to cropping areas, or be integrated with plot-based measurement to scale up information on tangible ESS/ESF, such as the inventory of forestry resources (Tomppo et al. 2008), productivity (del Barrio et al. 2010) and biodiversity (Kuemmerle et al. 2010b). Details on individual case studies can be found in Schneibel et al. (2013), Stellmes et al. (2013b), and in the factsheet section (all this issue).

In the line of the TFO strategy of multiscale assessment, the potential associated 
with the combination of the different remote sensing observation scales will be specifically explored, since full understanding of scale-dependencies is a prerequisite to the extrapolation of indicators mapped at plot or core site level to the FORA area (Hansen et al. 2008).

\section{Socio-economic evaluation}

\section{Socio-economic assessment/Societal values}

The main purpose of the social science contribution is the assessment of the strength and direction of key human (social-cultural and economic) drivers of change for the social ecological system of the Okavango. Cumulative effects are basically routed in transforming land use strategies, which are in turn driven mainly by changing values or revaluations of strategies. It is multiple people on different scales who impact and transform the ecological basis of livelihoods with various cumulative effects. While TFO attempts to gain a sufficient picture of the related stakeholder landscape (see Schmidt et al. 2013), it cannot investigate all relationships between global actors and local land users empirically. Therefore, a set of empirical methodological approaches has been chosen that allow understanding the changes in human valuation and land use strategies and their effects with ESS which are mainly concentrating on the local land use and regional/national governance levels.

\section{Valuation assessment}

The assessment of valuation by multiple stakeholders is informed by the biophysical and socio-economic information gathered in all other assessments (Cowling et al. 2008). In this context, it is important to assess the linkages between cultural and economic valuation happening within a transforming and not at all conflict free institutional and governance framework. This requires the collaboration of several disciplines. The study of both the nature-related values (beliefs) that people hold, and of the values people assign (in monetary or ranking terms) to nature has been shown to be contentious (Cowling et al. 2008). Valuing is as much concerned with the monetary worth of something as with personal judgment of worth (nonmonetary values). In practice, different forms for valuation illustrate this range in the meaning of valuation. While economic valuation provides help to understand societal preferences, cultural valuation provides a link between the maintenance of an ESS and the identity of stakeholder groups. Finally, ecological valuation gives an indication on the state of nature, e.g. indices of nature integrity or energy analysis (de Groot et al. 2010).

Valuation exercises can have several purposes and approaches to valuation should be chosen accordingly. Monetary valuation of ESS or of ecosystems can be assessed simply in order to raise awareness about the worth of ecosystem services for decision makers, but has also been used to choose between land use projects (Cowling et al. 2008, Spash 2008, Pritchard et al. 2000). Monetary valuation aims at calculating the Total Economic Value (TEV), which consists of the sum of the direct use values, options values and non-use values of the object to be valued (Pearce and Warford 1993). In TFO, we use monetary valuation mostly for the purpose of raising awareness on the value of soil quality and water supply and providing input data for the design of a payment for ecosystem services scheme.

While monetary valuation has proven helpful for the allocation of given land uses in the UK (Bateman et al. 2011), its inherent limitations can render it a method less helpful in a context where large uncertainties occur, populations are less integrated in a monetary economy, and groups with strong differences in power and cultural background have different stakes with regard to land use (Cowling et al. 2008, Spangenberg \& Settele 2010). Nonmonetary and intangible (e.g. spiritual) values - often too easily subsumed under "cultural values" and hidden as a sub-aspect in ESS frameworks - play an enormously important role in valuing land uses and the importance of ESS for livelihoods and strategies. Actually people's choices for a good and better life are highly dependent on shared, cultural and rapidly transforming values, which cannot always be assessed in monetary terms.

To represent such values in a spatially useable way ethnography including longterm fieldwork has been applied to explore stakeholder's valuation of surrounding ecosystems and landscapes. During fieldwork in Angola, Namibia and Botswana, the anthropological team has collected participatory landscape value mappings (Fagerholm et al. 2012, Raymond et al. 2009, Brown et al. 2012) to visualize locally perceived ESS in space. Local level informants marked places in the surroundings of their community that they perceived as important (e.g. places for experiencing beauty) by placing stickers on a printed satellite image. Then spatial parameters and attribute data were analysed and the intensity of the point data in space was displayed in density surfaces (Silverman 1986). Yet, not all processes of cultural valuation can be assessed with such mapping exercises and often cannot be quantified. Therefore, additionally a mix of quantitative and qualitative methodology was used, including in-depth open-ended and semi-structured interviews, participant observation and ranking tasks (Rieprich 2013).

\section{Integrated assessment and modelling concepts}

Based on the discipline-specific measurements, analyses and assessments carried out at different scales, it is essential to integrate these to understand interactions between physical and socioeconomic drivers and their cumulative impact on ESS/ESF.

In a first iteration, this integration may be pursued on the level of the different mapping scales introduced. For example, major ESS such as Crop and Vegetable Growth, Thatch Grass Growth or Wild Species Diversity are assessed at the local scale by analysing soil functions, yields, mapping species occurrence, and assessing the way in which these ESS are used both by local residents and, potentially, companies with external relations. Then, earth observation and geospatial modelling may be used to extrapolate these findings to the regional and FORA scale. More generic functions, such as water supply or climate regulation are rather assessed at the FORA level to provide a background for local analyses.

On a spatially explicit level, combining data normalization techniques and map overlay functions may serve to attain integrated maps of ESS (Petter et al. 2012). Alternatively, smaller numbers of domains (e.g. plot, sub-basins) may be integrated based on specific conceptual models to represent basin-wide ESS. For instance, the integration of long-term, gridded climate data with corresponding time series of vegetation indicators allows assessing the productivity of ecosystems in a climatically unbiased manner using rain use efficiency as a proxy (Wessels et 
al. 2007, del Barrio et al. 2010). Similarly, carbon bookkeeping models (Houghton \& Hackler, 1999) enable the representation of carbon cycles and $\mathrm{CO}_{2}$-emissions under different climate scenarios and across large scales (Houghton \& Hackler 2006, Kuemmerle et al. 2010a). At a higher integration level, major emphasis is put on incorporating both physical and socioeconomic domains, which is mandatory to understand land use decisions at the plot level, and addressing trade-offs at higher levels. For instance, integrating spatiotemporal data with household survey data may illustrate actors decisions (Lorent et al. 2008), and the consideration of land users perspective through specific interviews, combined with targeted analyses of specific indicators may facilitate the development of land management concepts accepted by stakeholders (Rojo et al. 2012).

Moving beyond local case studies, integrated concepts may help to assess ESS at large areas and under explicit consideration of cumulative, aggregated effects. These include the syndrome approach (Lüdeke et al. 2004) that describes bundles of interactive processes and symptoms which appear repeatedly and in many places in typical combinations and patterns (Hill et al. 2008, Stellmes et al. 2013a). The Human Appropriation of Net Primary Production (HANPP) represents the aggregate impact of land use on biomass available each year in ecosystems as a measure of the human domination of the biosphere, and is based on vegetation indicators, agricultural and forestry statistics, and geographical information systems data on land use, land cover, and soil degradation (Haberl et al. 2002, Erb et al. 2009a, 2009b).

While such approaches provide insight into specific compartments of the ESS/ESF portfolio addressed by TFO, the assessment of trade-offs between different land use options and resulting ESS/ESF can be based on different evaluation methods such as multi-criteria decision analysis involving stakeholder boards (Figueira et al. 2005, Curtis 2004, Chee 2004). In TFO, multi-criteria-approaches will be used to explicitly address where trade-offs occur and who are "winners" and "losers" in given scenarios of land use. As an important factor, the development of scenarios attempts to describe all the drivers of societal change that impact on ESS by combining local expert knowledge and literature research at the FORA and core site scales, since ESS related to land use choices in one scale may affect ESS provision at another scale (Biggs et al. 2007, Zurek \& Henrichs 2007). In particular, one goal is to address social decision processes (e.g. future planned projects) in a spatially explicit manner to enable the development of future scenarios as a base for managing and planning these processes. Besides their integration capabilities, scenarios are also an important element in identifying cumulative effects both from past or present actions, as well as those that may occur as a result of processes happening in other regions that are functionally connected.

Another option for integrating diverse assessments is based on the conceptual framework for comparative assessment introduced by Foley et al. (2005). This provides a framework for comparing the provision of ESS/ESF for a given land use unit and under a given utilization scenario making use of flower-diagrams. Thereby, it enables the comparison of ESS/ESF between different systems, as well as across systems with different management or utilization scenarios, and illustrates substitution effects occurring as a result of different types of management. Figure 6 illustrates a potential realization for two land use units located in Northern Namibia. It is based on field assessments of soil properties, crop yields, and the presence and abundance of different types of vegetation. It is complemented by remote sensing based assessments of the spatial extension and configuration of these land use types as well estimates of tree cover. Hydrological models incorporating ground-based measurements as well as remotely sensed land use and land cover maps provide comparable information on the hazard regulation properties of the two systems as well as their impact on water supply, while climatological models provide a larger spatial context. Interviews with stakeholders as well as landscape value mapping exercises have been carried out to understand the personal situation of actors as well as the decision they take on utilizing natural resources. While such information is important to characterize the Environmental Setting ESS, it is also essential to interpret the information conveyed in the flower diagrams from a stakeholder perspective. Further information on the individual aspects of these studies may be found in the contributions by Pröpper et al., (2013), Herold et al. (2013) and Gröngröft et al. (2013, all this issue). Apparently, the "Natural ecosystem" situation leads to a higher overall quality of ESS provision, and at the same time to less negative cumulative off-site effects (in particular downstream). On the other hand, despite its lower overall rating, "Irrigated cropland" shows a significant increase in crop and vegetable production, which is often one of the most important development targets in terms of food security. However, it is associated with lower ratings concerning variables that might cause negative cumulative off-site effects. These pertain to the extraction of water for irrigation that might cause reduction in available water and water quality in downstream locations, as well as the regulation potential for the prevention of floods. Finally, the "Environmental Setting" parameter incorporates the perception of local stakeholders, and the preferences expressed should be strongly considered in the evaluation. Accordingly, when comparing two scenarios, both direct ESS-related effects, as well as the estimation of cumulative off-site effects needs to be considered.

This concept is flexible and allows addressing the most relevant ESS/ESF in a consistent way, while considering historical and political framework conditions to formulate recommendations to meet specific management or development goals (Reyers et al. 2009).

Whether such models can be implemented for a specific region, or if semi-quantitative approaches, such as the flower-diagrams, are preferred, depends on the complexity of underlying drivers of ESS and their cumulative effects, as well as the availability of appropriate data. Ideally, these should cover sufficiently large areas and representative environmental and societal gradients. Whichever approach is chosen, any factor considered needs to be carefully measured and be accompanied by a thorough documentation of associated error margins. This is crucial to ensure the results of integrated ESS analyses can serve as a credible baseline to inform decision-makers and stakeholders of the expected outcomes of land use decisions.

\section{Conclusions}

In the context of the TFO project, some major challenges emerge from the conceptual considerations discussed before. Opposed to other studies with less variable settings, local processes in the Okavango Basin are driven by a 

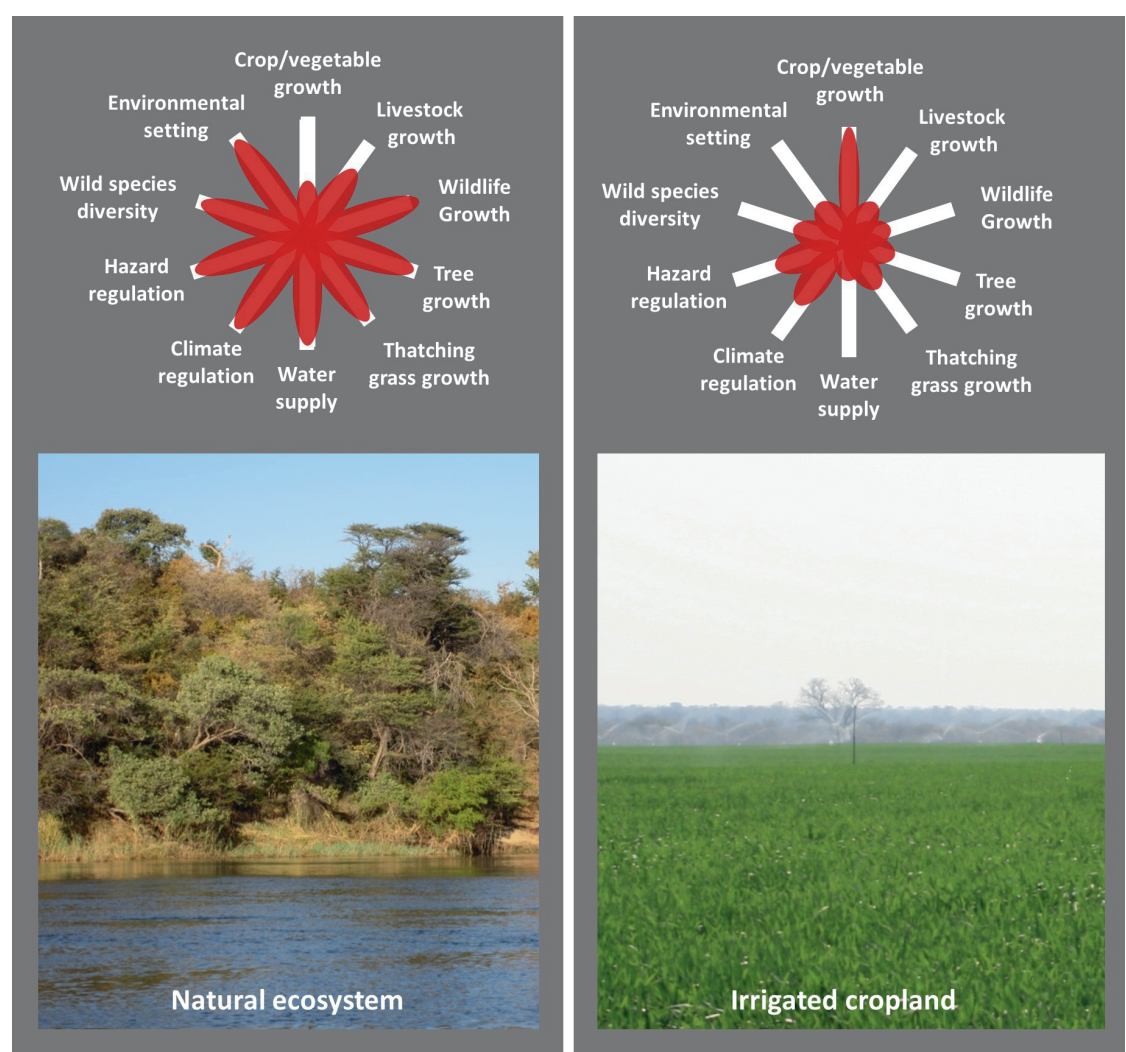

Fig. 6: Hypothetical example of ESS/ESF supplied from a natural ecosystem vs. an irrigated cropland system along the middle reaches of the Okavango river (figure adapted from Foley et al. 2005). A detailed explanation is found in the text.

combination of highly individual land use decisions between the aspiration of modernization and the conservation of cultural traditions, and centralized policies, all of which are interfaced by regional bodies with varying degrees of effectiveness.

In addition, strong differences exist between different regions and across the catchment in terms of the availability of credible scientific and administrational information, and the level to which stakeholders and administrations are able and ready to contribute to such an analysis (and to understand their outcomes). Therefore, an important element of the project is the collation of baseline information in the different disciplines to ensure a minimum common standard of reference information for the selected core areas. This baseline information is primarily collected at the plot and coresite levels, with the goal of representing major socio-ecological units along the Basin and to support upscaling to the whole research area (FORA).

As stated before, cumulative effects between different processes may occur in the spatial and temporal dimension; depending on the method employed for data integration, these need to be

explicitly described or, in the case of model-based integration, be quantified. However, one should be aware that even in the case of exhaustive analyses of ESS, not all cumulative effects may be determined or quantified with the same degree of accuracy (or, potentially, not be addressed at all), and that the list of such effects depends largely on the system understanding of the respective disciplines and the information gained from cooperation with stakeholders. Therefore, any recommendations for enhanced land use management developed from the integrated analysis need to be accompanied by an estimation of the accuracy at which the underlying assessment has been carried out.

In the context of the project, the different parameters of cumulative effects are mainly addressed using spatially explicit development scenarios and results attained from large area mapping and long-term datasets. The interdisciplinary development of scenarios brings together a wide range of expertise and numerous perspectives on the same areas, thus providing an ideal framework to identify interlinkages between multi-scale human actions and different ecosystem processes and their potential impact on ESS. On the other hand, spatially explicit, grid based modelling, as well as the analysis of longterm records of earth observation data, intrinsically capture the impact of cumulative effects across space and time. Integrating these with the scenario-based knowledge base therefore provides an important means of enhancing the understanding of cumulative effects and integrating this knowledge into the formulation of recommendations for land use management.

Reflecting the demands for spatially explicit planning data, recent initiatives aim at a quantitative and fully modelbased, integrated valuation of ecosystem services and trade-offs associated with management decisions. In this context, ARtifical Intelligence for Ecosystem Sevices (ARIES, Bagstad et al. 2013) model and the Integrated Valuation of Ecosystem Services and Tradeoffs (InVEST, Kareiva et al. 2011) model utilize sub-models for different ecosystem services, enabling to accommodate factors according to their relevance and data availability. Once the qualitative integration of results has successfully been achieved, the next step will be the integration of the data collected at various scales in such a fully quantitative, modelbased manner.

\section{Acknowledgements}

The "Future Okavango" project is funded by the German Federal Ministry of Education and Research (BMBF) in the frame of the funding measure "Sustainable Land Management". This support is gratefully acknowledged. The authors wish to thank two reviewers for providing helpful comments and suggestions that greatly helped to improve the manuscript

\section{References}

Abdelli, H., Jouen, D. (2012): Diagnóstico Agrário Territorial da Província do Bie. Municipios do Andulo e Chitembo, 110. Rome: FAO Angola - Projecto TERRA.

Allen, T.F.H., Starr, T.B. (1982): Hierarchy: Perspectives for Ecological Complexity. - Chicago, Illinois, USA: University of Chicago Press.

Bagstad, K.J., Johnson, G.W., Voigt, B., Villa, F. (2013): Spatial dynamics of ecosystem service flows: A comprehensive approach to quantifying actual services. - Ecosystem Services 4: 117-125.

Banwart, S. (2011): Save our soils. - 
Nature 474: 151-152. CrossRef

Bateman, I., Mace, G.M., Fezzi, C., Atkinson, G., Turner, K. (2011): Economic Analysis for Ecosystem Assessments. - Environmental Research Economics 48: 177-218. CrossRef

Baumberg, V., Helmschrot, J., Göhmann, H., Steudel, S., Fischer, C. \& Flügel, WA. (2014): Vergleichende hydrologische Modellierung und Bewertung der Abflussdynamik zweier Zuflüsse des Okavango-Flusses. Zentralblatt für Geologie und Paläontologie; Teil I (in press).

Beven, K.J. (2001): How far can we go in distributed hydrological modelling? Hydrology and Earth System Sciences 5(1): 1-12.

Biggs, R., Raudsepp-Hearne, C., AtkinsonPalombo, C., Bohensky, E., Boyd, E., Cundill, G. Fox, H., Ingram, S, Kok, K., Spehar, S., Tengo, M., Timmer, D., Zurek, M. (2007): Linking futures across scales: a dialog on multiscale scenarios. - Ecology and Society 12(1): Article 17.

Blöschl, G. (2006): Hydrologic synthesis: across processes, places, and scales. Water Resources Research 42: W03S02 CrossRef

Bouma, J. (2000): Land Evaluation for Landscape Units. - In: Sumner, M.E. [Ed.]: Handbook of Soil Science, 393-412. Boca Raton: CRC Press.

Brown, G., Montag, J. M., Lyon, K. (2012): Public Participation GIS: A Method for Identifying Ecosystem Services. Society \& Natural Resources 25(7): 633-651. CrossRef

Butchart, S.H.M., Walpole, M., Collen, B., van Strien, A., Scharlemann, J.P.W., Almond R.E.A., Baillie J.E.M., Bomhard, B., Brown, C., Bruno, J., Carpenter, K.E., Carr, G.M., Chanson, J., Chenery, A.M., Csirke, J., Davidson, N.C., Dentener, F., Foster, M., Galli, A., Galloway, J.N., Genovesi, P., Gregory, R.D., Hockings, M., Kapos, V., Lamarque, J.-F., Leverington, F., Loh, J., McGeoch, M.A., McRae, L., Minasyan, A., Hernández Morcillo, M., Oldfield, T.E.E., Pauly, D., Quader, S., Revenga, C., Sauer J.R., Skolnik, B., Spear, D., Stanwell-Smith, D., Stuart, S.N., Symes, A., Tierney, M., Tyrrell, T.D., Vié, J.-C., Watson, R. (2010): Global biodiversity: indicators of recent declines. - Science 328: 1164-1168. CrossRef

Carpenter, S.R., DeFries, R., Mooney, H.A., Polasky, S., Reid, W., Scholes, R.J. (2006): Millennium Ecosystem Assessment: Research Needs. Science 313: 257-258. CrossRef

Chapin, F.S., Carpenter, S.R., Kofinas, G.P., Folke, C., Abel, N., Clark, W.C., Olsson, P., Stafford Smith, D.M., Walker, B., Young, O.R., Berkes, F., Biggs, R., Grove, J.M., Naylor, R.L., Pinkterton, E., Steffen, W., Swanson, F.J. (2009): Ecosystems stewardship: sustainability strategies for a rapidly changing planet. - Trends in Ecology and Evolution 25 . 241-249. CrossRef

Chee, Y.E. (2004): An ecological perspective on the valuation of ecosystem services. - Biological Conservation 120: 549-565. CrossRef

Coetzee, M.E. (2001): NAMSOTER, a SOTER database for Namibia. Windhoek: Ministry of Agriculture, Water and Rural Development.

Costanza, R., (2008): Ecosystem Services: Multiple classification systems are needed. - Biological Conservation 141: 350-352. CrossRef

Cowling, R.M., Egoh, B., Knight, A.T., O'Farrell, P., Reyers, B., Rouget, M., Roux, D.J., Welz, A., Wilhelm-Rechman, A. (2008): An Operational Model for mainstreaming ecosystem services for implementation. - PNAS 105: 9483-9488. CrossRef

Curtis, I.A. (2004): Valuing ecosystem goods and services: a new approach using a surrogate market and the combination of a multiple criteria analysis and a Delphi panel to assign weights to the attributes. - Ecological Economics 50: 163-194. CrossRef

DeFries, R., Foley, J.A., Asner, G.P. (2004): Land-use choices: balancing human needs and ecosystem function. Frontiers in Ecology and Environment 2: 249-257. CrossRef

de Groot, R.S., Alkemade, R., Braat, L., Hein, L., Willemen, L. (2010): Challenges in integrating the concept of ecosystem services and values in landscape planning, management and decision making. - Ecological Complexity 7: 260-272. CrossRef

del Barrio, G., Puigdefabregas, J., Sanjuan, M.E., Stellmes, M., \& Ruiz, A. (2010): Assessment and monitoring of land condition in the Iberian Peninsula, 1989-2000. - Remote Sensing of Environment 114: 1817-1832. CrossRef

De Wit, P.V., Nachtergaele. F., (1990): Explanatory note on the soil map of the Republic of Botswana at scale 1:1.000.000, 48. - Gabarone: FAO, UNDP, Gouvernment of Botswana.

Dominati, E., Patterson, M., Mackay., A. (2010): A framework for classifying and quantifying the natural capital and ecosystem services of soils. - Ecological Economics 69(9): 1858-1868. CrossRef

Domptail, S.E., Nuppenau, E.-A., Azebaze, N., Brown, L.D., Falk, T., Finckh, M., Große, L.M., Kowalski, B., Pröpper, M., Stellmes, M., Overmann, J. (2013): Using trade-offs and synergies in ecosystem services in resource management. - Biodiversity \& Ecology 5: 185-193. CrossRef

Ellis, E.C., Ramankutty, N. (2008): Putting people in the map: anthropogenic biomes of the world. - Frontiers in Ecology and the Environment 6: 439-447. CrossRef
Erb, K.-H., Krausmann, F., Gaube, V., Gingrich, S., Bondeau, A., FischerKowalski, M., Haberl, H. (2009a): Analyzing the global human appropriation of net primary production processes, trajectories, implications. An introduction. - Ecological Economics 69: 250-259. CrossRef

Erb, K.-H., Krausmann, F., Lucht, W., Haberl, H. (2009b): Embodied HANPP Mapping the spatial disconnect betweenn global biomass production and consumption. - Ecological Economics 69: 328-334. CrossRef

Eschenbach, A., Gröngröft, A., Overmann, J., Wüst, P., Huber, K., LutherMosebach, J., Landschreiber, L, Masamba, W., Mubyana-John, T., Zimmermann, I. (2013): Evaluation of soil functions and microbial biodiversity to indicate ecosystem services in the Okavango catchment. - URL: http://www.future-okavango.org/ downloads/LAMA_StatusConference_Ap ril2013/08_130417_Eschenbach_Soil_E SF_Statusseminar.pdfStatuskonferenz.

Fagerholm, N., Kayhko, N., Ndumbaro, F., Khamis, M. (2012): Community stakeholders' knowledge in landscape assessments - Mapping indicators for landscape services. - Ecological Indicators 18: 421-433. CrossRef

Figueira, J., Greco, S., Ehrgott, M. (2005): Multiple Criteria Decision Analysis: State of Art Surveys. - Boston, Dordrecht, London: Springer.

Fink, M., Krause, P., Kralisch, S., BendeMichl, U., Flügel, W.-A. (2007): Development and application of the modelling system J2000-S for the EUwater framework directive. - Advances in Geoscience 11: 123-130, CrossRef

Fisher, B., Turner, K., Morling, P. (2009): Defining and classifying ecosystem services for decision making. Ecological Economics 68: 643-653. CrossRef

Flügel, W.-A. (1995): Delineating Hydrological Response Units (HRU's) by GIS analysis for regional hydrological modelling using PRMS/MMS in the drainage basin of the River Bröl, Germany. - Hydrological Processes 9 : 423-436. CrossRef

Flügel, W.-A., Smith, R.E. (1999): Integrated process studies and modelling simulations of hillslope hydrology and interflow dynamics using the HILLS model. - Environmental Modelling \& Software 14: 153-160. CrossRef

Foley, J., DeFries, R., Asner, G.P., Barford, C., Bonan, G., Carpenter, S.R., Chapin, F.S., Coe, M.T., Daily, G.C., Gibbs, H.K. Helkowski, J.H., Holloway, T., Howard, E.A., Kucharik, C.J., Monfreda, C., Patz, J.A., Prentice, I.C., Ranankutty, N., Snyder, P.K. (2005): Globals consequences of land use. - Science 309: $570-574$. CrossRef 
Franklin, J. (2011): Mapping species distributions: spatial inference and prediction. - Cambridge: Cambridge University Press.

Gillson, L. (2009): Landscapes in Time and Space. - Landscape Ecology 24: 149-155. CrossRef

Gröngröft, A., Luther-Mosebach, J., Landschreiber, L., Kowalski, B. (2013): A method for yield assessment on dryland agricultural fields. - Biodiversity \& Ecology 5: 279-286. CrossRef

Haberl, H., Krausmann, F., Erb, K.-H., Schulz, N.B., Rojstaczer, N.B., Sterling, S.M., Moore, N. (2002): Human appropriation of net primary production. - Science 296: 1968-1969. CrossRef

Hansen, M., Roy, D.P., Lindquist, E., Adusei, B., Justice, C.O., Altstatt, A. (2008): A method for integrating MODIS and Landsat data for systematic monitoring of forest cover and change in the Congo Basin. - Remote Sensing of Environment 112: 2495-2513. CrossRef

Hegmann, G., Cocklin, C., Creasey, R., Dupuis, S., Kennedy, A., Kingsley, L., Ross, W., Spaling, H., Stalker, D. (1999): Cumulative Effects Assessment Practicioners Guide. - Canadian Environmental Agency [Ed.]. Hull, Quebec.

Hein, L., van Koppen, K., de Groot, R.S., van lerland, E.C. (2006): Spatial scales, stakeholders and the valuation of ecosystem services. - Ecological Economics 57: 209-228. CrossRef

Herold, B., Große, L.M., Domptail, S.E., Kgathi, D.L., Falk, T., Azebaze, N., Kowalski, B. (2013): Livelihood diversification in a rural community of the Okavango Delta, Botswana. Biodiversity \& Ecology 5: 363-377. CrossRef

Helmschrot, J. (2006): An integrated, landscape-based approach to model the formation and hydrological functioning of wetlands in semiarid headwater catchments of the Umzimvubu River, South Africa. - Göttingen: Sierke Verlag.

Hill, J., Stellmes, M., Udelhoven, T., Röder, A., Sommer, S. (2008): Mediterranean desertification and land degradation. Mapping related land use change syndromes based on satellite observations. - Global and Planetary Change 64: 146-157. CrossRef

Houghton, R.A., Hackler, J.L. (2006): Emissions of carbon from land use change in sub-Saharan Africa. - Journal of Geophysical Research 111: G02003. CrossRef

Houghton, R.A., Hackler, J.L. (1999): Emissions of carbon from forestry and land-use change in tropical Asia. Global Change Biology 5: 481-492. CrossRef

Imhoff, M.L., Bounoua, L., Ricketts, T., Loucks, C., Harriss, R., Lawrence, W.T. (2004): Global patterns in human consumption of net primary production. -
Nature 429: 870-873. CrossRef

Jack, B.K. (2009). Upstream-downstream transactions and watershed externalities: Experimental evidence from Kenya. Ecological Economics 68: 1813-1824. CrossRef

Jakeman, A.J., Letcher, R.A. (2003): Integrated assessment and modelling: features, principles and examples for catchment management.

Environmental Modelling \& Software 18: 491-501. CrossRef

Jensen, J. (2007): Remote sensing of the environment: an earth resource perspective. Upper Saddle River: Pearson Prentice Hall.

Jiang, L., Tarpley, J.D., Mitchell, K.E. Zhou, S., Kogan, F.N., Guo, W. (2008): Adjusting for long-term anomalous trends in NOAA's global vegetation index data sets. - IEEE Transactions on Geoscience and Remote Sensing 46 : 409-422. CrossRef

Jones, A., Breuning-Madsen, H., Brossard, M., Dampha, A., Deckers, J., Dewitte, O., Gallali, T., Hallett, S., Jones, R., Kilasara, M., Le Roux, P., Micheli, E., Montanarella, L., Spaargaren, O., Thiombiano, L., Van Ranst, E. Yemefack, M., Zougmoré, R. (2013) [Eds.]: Soil Atlas of Africa, 176. Luxembourg: European Commission.

Kalma, J.D., Feddes, R.A. (1993): Goals and implementation of the UNESCO/IHP Project H-1-1. Review of the scientific aspects of the interface processes of water transport through the atmospherevegetation-soil system at elementary plot, catchment and large-grid scales. IAHS Publ. 212: 13-17.

Kapur, S., Eswaran, H., Blum, W.R.H. (2010): Sustainable Land Management: Learning from the Past for the Future. New York, Heidelberg, London: Springer. Kareiva, P., Watts, S., McDonald, R. Boucher, T. (2007): Domesticated nature: shaping landscapes and ecosystems for human welfare. Science 316: 1866-1869. CrossRef

Kareiva, P., Tallis, H., Ricketts, T. (2011): Natural Capital: Theory \& Practice of Mapping Ecosystem Services. - Oxford: Oxford University Press. CrossRef

Koch, E.W., Barbier, W.B., Silliman, B.R., Reed, D.J., Perillo, G.M.E., Hacker, S.D., Granek, E.F., Primavera, H., Muthiga, N., Polysky, S., Halpern, B., Kennedy, C.J., Kappel, C.V., Wolanski, E. (2009): Non-linearity in ecoystem services: temporal and spatial variability in coastal protection. - Frontiers in Ecology and the Environment 7: 29-37. CrossRef

Kralisch, S., Fischer, C. (2012): Model representation, parameter calibration and parallel computing - the JAMS approach. - Proceedings of the International Congress on Environmental Modelling and Software, Sixth Biennial Meeting (R. Seppelt, A. A. Voinov, S.
Lange \& D. Bankamp [Eds.]). Leipzig, Germany.

Kralisch, S. Krause, P. (2006): JAMS - A Framework for Natural Resource Model Development and Application. - In: Voinov, A., Jakeman, A., and Rizzoli, A. [Eds.]: Proceedings of the iEMSs Third Biannual Meeting "Summit on Environmental Modelling and Software". - Burlington, USA.

Krause, P. (2001): Das hydrologische Modellsystem J2000 - Beschreibung und Anwendung in großen Flußgebieten. 29. Schriften des Forschungszentrums Jülich, Reihe Umwelt/Environment.

Krause, P., Bende-Michl, U., Fink, M., Helmschrot, J., Kralisch, S., Künne, A. (2009): Parameter sensitivity analysis of the JAMS/J2000-S model to improve water and nutrient transport process simulation - a case study for the Duck catchment in Tasmania. - In: Anderssen, R., Braddock, R., Newham, L. [Eds.]: Proceedings of the 18th World IMACS Congress and MODSIM09 International Congress on Modelling and Simulation (Cairns, Australia): 3179-3186.

Kremen, C., Ostfeld, R.S. (2005): A call to ecologists: measuring, analyzing and managing ecosystem services. Frontiers in Ecology and Environment 3(10): 540-548. CrossRef

Kroes, J.G., Van Dam, J.C., Groenendijk, P., Hendriks, R.F.A., Jacobs., C.M.J. (2008): SWAP version 3.2. Theory and user manual. - Wageningen: Alterra.

Kuemmerle, T., Olofsson, P., Chaskovskyy, O., Baumann, M., Ostapowicz, K., Woodcock, C.E., Houghton, R.A., Hostert, P., Keeton, W.S., Radeloff, V.C. (2010a): Post-Soviet farmland abandonment, forest recovery, and carbon sequestration in western Ukraine. - Global Change Biology 17: 1335-1349. CrossRef

Kuemmerle, T., Perzanowski, K., Chaskovskyy, O., Ostapowicz, K., Halada, L., Bashta, A.-T., Hostert, P., Waller, D.M., Radeloff, V.C. (2010b): European bison habitat in the Carpathian Mountains. - Biological Conservation 143: 908-916. CrossRef

Lal, R. (2013): Climate-strategic agriculturae and the water-soil-waste nexus. - Journal of Plant Nutrition and Soil Science 176: 479-493. CrossRef

Lambin, E.F., Meyfroidt, P. (2011): Global land use change, economic globalization and the looming land scarcity. Proceedings of the National Academy of Sciences 108: 3465-3472. CrossRef

Leavesley, G.H., Lichty, R.W., Troutman, B.M. Saindon, L.G. (1983): Precipitation Runoff Modelling System. User's manual. Technical Report 83-4238, USGS Water Resources Investigations.

Leenaars, J.G.B. (2013): Africa Soil Profiles Database, Version 1.1. A compilation of geo-referenced and standardized legacy soil profile data for 
Sub Saharan Africa (with dataset). Wageningen: ISRIC - World Soil Information.

Lindemann, S. (2009): Success and failure in international river basin management - the case of Southern Africa - In: Brauch, H.-G., Oswald Spring, U., Grin, J., Mesjasz, C., Kameri-Mbote, P., Chadha Behera, N., Chourou, B., Krummenacher, H. [Eds.]: Facing global environmental change: environmental, human, energy, food, health and water security concepts 699-710. - Springer: Berlin. CrossRef

Liu, J., Dietz, T., Carpenter, S.R., Alberti, M., Folke, C., Moran, E., Pell, A.N., Deadman, P., Kratz, T., Lubchenko, J., Ostrom, E., Ouyang, Z., Provencher, W., Redman, C.L., Schneider, S.H., Taylor, W.W. (2007): Complexity of Coupled Human and Natural Systems. - Science 317: 1513-1516. CrossRef

Lorent, H., Evangelou, C., Stellmes, M., Hill, J., Papanastasis, V.P., Tsiourlis, G., Röder, A., Lambin, E.F. (2008): Land degradation and economic conditions of agricultural households in a marginal region of northern Greece. - Global and Planetary Change 64: 198-209. CrossRef

Luck, G.W., Harrington, R., Harrison, P.A., Kremen, C., Berry, P.M., Bugter, R., Dawson, T.P., de Bello, F., Díaz, S., Feld, C.K., Haslett, J.R., Hering, D., Kontogianni, A., Lavorel, S., Rousevell, M., Samways, M.J., Sandin, L., Settele, J., Sykes, M.T., van den Hove, S., Vandewalle, M., Zobel, M. (2009): Quantifying the contribution of organisms to the provision of ecosystem services. Bioscience 59: 223-35. CrossRef

Lüdeke, M.K.B., Petschel-Held, G., Schellnhuber, H.J. (2004): Syndromes of global change: the first panoramic view. - Gaia 13: 42-49.

Martín-López, B., García-Llorente, M., Palomo, I., Montes, C., (2011): The conservation against development paradigm in protected areas: Valuation of ecosystem services in the Doñana social- ecological system (southwestern Spain). - Ecological Economics 70 1481-1491. CrossRef

Mbaiwa, J.E., Mbaiwa, O.I., (2006): The effects of veterinary fences on wildlife populations in Okavango Delta, Botswana. - International Journal of Wilderness 12(3): 17-41.

Mendelsohn, J. (2009): Land Use in Kavango: Past, Present and Future. - In: Okavango River Basin Transboundary Diagnostic Analysis Technical Report: Socioeconomic Series. - OKACOM (The Permanent Okavango River Basin Water Commission), Airport Industrial, Maun, Botswana, 31: RAISON (Research and Information Services of Namibia).

Millenium Ecosystem Assement (MEA) (2005): Ecosystems and human wellbeing: synthesis. - Washington: Island
Press.

Ministry of Environment and Tourism, Directorate of Environmental Affairs (2000): Natural Resource Mapping of the Kavango Region, 53. - Windhoek: Ministry of Environment and Tourism.

Morán-Ordóñez, A., Bugter, R., SuárezSeoane, S., de Luis, E., Calvo, L. (2013): Temporal Changes in SocioEcological Systems and Their Impact on Ecosystem Services at Different Governance Scales: A Case Study of Heathlands. - Ecosystems 16(5): 765-782.

Mulligan, M., Burke, S.M., Ramos, M.C. (2004): Climate change, land-use change and "desertification" of Mediterranean Europe. In: Mazzoleni, S., di Pasquale, G., Mulligan, M., di Martino, P., Rego, F. [Eds.]: Recent Dynamics of the Meditteranean Vegetation and Landscape 259-279. Chichester: Wiley \& Sons. CrossRef

O'Neill, R.V., DeAngelis, D.L., Waide, J.B., Allen, T.F.H. (1986): A hierarchical concept of ecosystems. Princeton, New Jersey, USA: Princeton University Press.

Pal, M., Mather, P.M. (2005): Support vector machines for classification in remote sensing. - International Journal of Remote Sensing 26: 1007-2011. CrossRef

Pearce, D.W., Warford, J.J. (1993): World Without End - Economics, Environment and sustainable development. - New York, Oxford: University Press, Inc.

Petter, M., Mooney, S., Maynard, S.M., Davidson, A., Cox, M., Horosak, I. (2013): A Methodology to Map Ecosystem Functions to Support Ecosystem Services Assessments. Ecology and Society 18. CrossRef

Phalan, B., Onial, M., Balmford, A., Green, R.E. (2011): Reconciling food production and biodiversity conservation: land sharing and land sparing compared. Science 333: 1289-1291. CrossRef

Pickett, S.T.A (1989): Space-for-Time Substitution as an Alternative to LongTerm Studies. In: Likens, G.E [Ed.]: Long-Term Studies in Ecology 110-135. - New York: Springer.

Pröpper, M., Falk, F., Domptail, S.E., Große, L.M., Kowalski, B. (2013): Partly subsistent household economies and modern consumerism in the Namibian Kavango: Assets, income, expenditure and socio-economic stratification. Biodiversity \& Ecology 5: 379-391. CrossRef

Pritchard, L. Jr., Folke, C., Gunderson L. (2000): Valuation of Ecosystem Services in Institutional Context. - Ecosystems 3: 36-40. CrossRef

Raymond, C.M., Bryan, B.A., MacDonald, D.H., Cast, A., Strathearn, S., Grandgirard, A., Kalivas, T. (2009): Mapping community values for natural capital and ecosystem services. Ecological Economics 68(5):
1301-1315. CrossRef

Reyers, B., O'Farrell, P.J., Cowling, R.M., Egoh, B.N., Le Maitre, D., Vlok, J.H.J. (2009): Ecosystem services, land-cover change, and stakeholders: finding a sustainable foothold for a semiarid biodiversity hotspot. - Ecology and Society 14: 1-23.

Rhemtulla, J.M., Mladenoff, D.J. (2007): Why history matters in landscape ecology. - Landscape Ecology 22: 1-3. CrossRef

Rieprich, R. (2013): Mapping Environmental Valuations. An Ethnographic Case Study of Ecosystem Services and Landscape Values in Kavango, Namibia. Unpublished MA Thesis. Institute of Social and Cultural Anthropology. Hamburg: University of Hamburg.

Robinson, D.A., Lebron, I. (2010): On the natural capital and ecosystem services of soils. - Ecological Economics 70(2): 137-138. CrossRef

Röder, A., Kuemmerle, T., Hill, J. (2005): Extension of retrospective datasets using multiple sensors. An approach to radiometric intercalibration of Landsat TM and MSS data. - Remote Sensing of Environment 95: 195-210. CrossRef

Rogge, D.M., Rivard, B., Zhang, J., Feng, J. (2006): Iterative spectral unmixing for optimizing per-pixel endmember sets. IEEE Transactions on Geoscience and Remote Sensing 44: 3725-3736. CrossRef

Rojo, L., Bautista, S., Orr, B.J., Derak, M., Cortina, J., Vallejo, R.V. (2012): Prevention and restoration actions to combat desertification. An integrated assessment. PRACTICE project. Sécheresse 23: 216-226. CrossRef

Sala, O.E., Chapin III, F.S., Armesti, J.J., Berlow, E., Bloomfield, J., Dirzo, R., Huber-Sanwald, E., Huenneke, L.F., Jackson, R.B., Kinzig, A., Leemans, R., Lodge, D.M., Mooney, H.A., Oesterheld, M., Poff, N.L., Sykes, M.T., Walker, B.H. Walker, M., Wall, D.H. (2000): Global biodiversity scenarios for the year 2100 . - Science 287: 1770-1774. CrossRef

Scheffer, M. (2009): Critical transitions in nature and society. - Princeton: Princeton University Press.

Schneibel, A., Stellmes, M., Revermann, R., Finckh, M. (2013): Agricultural expansion during the post-civil war period in southern Angola based on multi-temporal Landsat data. Biodiversity \& Ecology 5: 311-319. CrossRef

Schulze, R.E. (1995): Hydrology and Agrohydrology: A Text to Accompany the ACRU 3.00 Agrohydrological Modelling System. Water Research Commission, Report TT69/95 Pretoria, South Africa.

Silverman, B. W. (1986): Density estimation for statistics and data analysis. - London: Chapman and Hall. CrossRef 
Smith, B.D. (2007): The ultimate ecosystem engineers. - Science 315: 1797-1798. CrossRef

Sommer, J.H., Kreft, H., Kier, G., Jetz, W., Mutke, J., Bartholott, W. (2013): Projected impacts of climate change on regional capacities for global plant species richness. - Proceedings of the Royal Society 277: 2271-2280. CrossRef

Spangenberg, J.H., Settele, J. (2010): Precisely incorrect? Monetizing the value of ecosystem services. - Ecologica complexity 7(3): 327-337. CrossRef

Spash, C. (2008): Ecosystem Services valuation. Socio-Economics and the Environment in Discussion. CSIRO Working Paper Series. - Canberra, CSIRO. Report $n^{\circ} 3$.

Steffen, W., Sanderson, A., Tyson, P.D., Jäger, J., Matson, P.A., Moore III, B., Oldfield, F., Richardson, K. Schellnhuber, H.J., Turner, I.L., Wasson, B.L.R. (2004): Global change and the earth system. - Berlin, Heidelberg, New York: Springer.

Stellmes, M., Röder, A., Udelhoven, T., Hill, J. (2013a): Mapping syndromes of land change in Spain with remote sensing time series, demographic and climatic data. - Land Use Policy 30: 685-702. CrossRef

Stellmes, M., Frantz, D., Finckh, M. Revermann, R. (2013b): The fire regime within the Okavango Catchment as seen by MODIS. - Biodiversity \& Ecology $\mathbf{5}$ 351-362. CrossRef

Steudel, T., Göhmann, H., Flügel, W.-A. Helmschrot, J. (2013): Hydrological assessment of hydrological dynamics in the upper Okavango. - Biodiversity \& Ecology 5: 247-261. CrossRef

Strohbach, B. J., Petersen., A. (2007) Vegetation of the central Kavango woodlands in Namibia: An example from the Mile 46 Livestock Development Centre. - South African Journal of Botany 73: 391-401. CrossRef

Tchiguirinskaia, I., Bonell, M. Hubert, P. (2004) [Eds.]: Scales in hydrology and water management. International Association of Hydrological Sciences (IAHS) Publication 287. 170 pp.

Tomppo, E., Olsson, H., Stahl, G., Nilsson, M., Hagner, O., Katila, M. (2008): Combining national forest inventory field plots and remote sensing data for forest databases. - Remote Sensing of Environment 112: 1982-1999.

Udelhoven, T., van der Linden, S., Waske, B., Stellmes, M. (2010): Hypertempora classification of large areas using decision fusion. - IEEE Geoscience and Remote Sensing Letters 6: 592-596. CrossRef

Weber, M., Krogman, N., Antoniuk, T. (2012): Cumulative Effects Assessment: Linking Social, Ecological, and Governance Dimensions. - Ecology and Society 17(2): 22 . CrossRef
Weber, T. (2013): Okavango Basing Climate. - Biodiversity \& Ecology 5: 15-17. CrossRef

Wessels, K.J. (2007): Can human-induced land degradation be distinguished from the effects of rainfall variability? A case study in South Africa. - Journal of Arid Environments 68: 271-297. CrossRef

Wisch, U., A. Petersen, A. Gröngröft, and A. Eschenbach. (2009): Dryland Farming in the Kavango Region: Effect of Land Use on Soil Properties. - Zentralblatt für Geologie und Paläontologie, Teil I 2008 (01. Feb): 189-211.

Wolski, P. Savenije, H.H.J., MurrayHudson, M. Gumbricht, T. (2006): Modelling of the flooding in the Okavango Delta, Botswana, using a hybrid reservoir-GIS model. - Journal of Hydrology 331: 58-72. CrossRef

Zhang, X., Friedl, M.A., Schaaf, C.B., Strahler, A.H., Hodges, J.C.F., Gao, F. Reed, B.C., Huete, A.R. (2003): Monitoring vegetation phenology using MODIS. - Remote Sensing of Environment 84: 471-475. CrossRef

Zurek, M.B., Henrichs, T. (2007): Linking scenarios across geographical scales in international environmental assessments - Technological Forecasting and Social change 74: 1282-1295. CrossRef

\section{Affiliations}

Achim Röder* (roeder@uni-trier.de), Marion Stellmes (stellmes@uni-trier.de), Anne Schneibel (schneibel.anne@unitrier.de), Johannes Stoffels (stoffels@unitrier.de)

Department of Environmental Remote Sensing and Geoinformatics, Faculty of Regional and Environmental Sciences, University of Trier

Behringstr. 21

54286 Trier, GERMANY

Stephanie Domptail,

(stephanie.domptail@agrar.uni-

giessen.de)

Institute for Agricultural Policy and

Market Research, University of Giessen

Senckenbergstrasse 3

35390 Giessen, GERMANY

Annette Eschenbach

(Annette.Eschenbach@ifb.unihamburg.de), Alexander Gröngröft (Alexander.Groengroeft@ifb.unihamburg.de)

Institute of Soil Science, University of Hamburg,

Allende-Platz 2

20146 Hamburg, GERMANY

Manfred Finckh (manfred.finckh@uni- hamburg.de), Jörg Helmschrot (joerg.helmschrot@uni-hamburg.de) Biodiversity, Evolution and Ecology of Plants (BEE), Biocentre Klein Flottbek and Botanical Garden, University of Hamburg, Ohnhorststr. 18 22609 Hamburg, GERMANY

Michael Pröpper

(michael.proepper@uni-hamburg.de) Institute for Social and Cultural Anthropology, University of Hamburg Edmund-Siemers-Allee 1, Flügelbau West 20146 Hamburg, GERMANY

${ }^{*}$ Corresponding author 
